\title{
Rancang Bangun Buck Konverter dengan Antarmuka Visual Studio
}

\author{
Muhammad Nur Khaliq ${ }^{1^{*}}$ Krismadinata $^{1}$ \\ ${ }^{1}$ Jursan Teknik Elektro FT UNP, Fakultas Teknik, Universitas Negeri Padang \\ *e-mail: m.nurkhaliq@gmail.com \\ (Diterima: 19 April 2020, direvisi: 12 Mei 2020, disetujui: 20 Mei 2020)
}

\begin{abstract}
Abstrak
Pada tulisan ini dibahas perancangan dan pembuatan dari konverter DC-DC (DC Chopper). Konverter DC-DC sendiri merupakan suatu alat yang dapat mengubah satu bentuk daya listrik searah ke bentuk daya listrik searah lainya, baik itu menurunkan atau menaikkan. Pada umumnya, rangkaian konverter terbagi atas 4 jenis yaitu buck, boost, buck-boost dan cuk. Pada pembuatan tugas akhir ini akan diracang sebuah rangkaian konverter DC-DC tipe Buck. Konverter Buck merupakan sebuah konverter yang digunakan untuk menghasilkan tegangan keluaran searah (DC) yang lebih rendah daripada tegangan masukannya. Penurunan tegangan keluaran dari konverter dilakukan dengan mengatur lebar pulsa (PWM). Pengubahan besar kecilnya PWM dilakukan dengan meggunakan komponen switching berupa MOSFET, serta penggunaan gate driver yang berfungsi sebagai penguatan sinyal dan pengaman antara rangkaian kontrol dan rangkaian utamanya. Tegangan masukan dari konverter dirancang sebesar 24 VDC, dengan tegangan keluaran 24VDC-12VDC. Keluaran dari konverter dapat dilihat melalui PC menggunakan software Visual Studio 2012. Penambahan interfacing menggunakan Visual Studio 2012 dapat memudahkan para pengguna untuk melihat keluaran dari konverter.
\end{abstract}

Kata Kunci: Buck Konverter, MOSFET, Gate Driver, Arduino Uno, Visual Studio

\begin{abstract}
This paper discusses the design and manufacture of DC-DC converters (DC Chopper). $D C-D C$ converter itself is a device that can change one form of electric power in the same direction to the form of electric power in the other direction, be it lowering or increasing. In general, the converter circuit is divided into 4 types, namely buck, boost, buck-boost and cuk. In making this final project will be designed a Buck-type DC-DC converter circuit. Buck Converter is a converter used to produce a direct output voltage (DC) that is lower than the input voltage. The decrease in the output voltage of the converter is done by adjusting the pulse width (PWM). Change the size of the PWM is done by using a switching component in the form of MOSFETs, as well as the use of a gate drive that serves as a signal and security reinforcement between the control circuit and its main circuit. The input voltage of the converter is designed at 24 VDC, with an output voltage of 24VDC-12VDC. The output of the converter can be seen through a PC using Visual Studio 2012. Adding interfacing using Visual Studio 2012 can make it easier for users to see the output of the converter.
\end{abstract}

Keywords: Buck Converter, MOSFET, Gate Driver, Arduino Uno, Visual Studio 


\section{PENDAHULUAN}

Kemajuan teknologi komponen dan rangkaian elektronika sudah bisa mewujudkankan metode penyedia daya tegangan searah (DC), yang dihasilkan melewati konversi input tegangan DC ke bentuk output tegangan DC yang lebih tinggi atau lebih rendah. Sebuah konverter DC/DC bisa dikembangkan dari rangkaian gabungan komponen semikonduktor jenis IGBT/ MOSFET[5]. Konversi tegangan DC ini awam disebut sebagai DC-DC konverter. Dalam metode penggantian daya DC atau DC-DC konverter, ada dua jenis yaitu jenis linier dan jenis peralihan atau jenis switching (DC chopper). Jenis linier minim diminati lantaran tingginya daya yang lenyap (power loss) pada transistor, sehingga berdampak rendahnya ketepatgunaan. Sedangkan pada jenis switching, semua daya terserap atas beban, sehingga ketepatgunaan daya menjadi $100 \%$. Akan tetapi pada prakteknya, tidak ada switch yang ideal[10].

Pada dasarnya, buck konverter menggambarkan salah satu tipe dari topologi switching power supply yang terdiri atas 2 bagian, yaitu bagian power dan bagian pengontrolan. Bagian power berguna untuk mengubah tegangan, yang tergolong komponen-komponen di dalamnya adalah switch dan filter output. Bagian pengontrolan berperan untuk mengontrol state $O N-O F F$ dari switch yang ditemukan di dalam rangkaian[4]. Buck konverter adalah konverter DC-DC yang dipakai untuk menurunkan tegangan DC. Prinsip kerja rangkaian ini adalah dengan kendali pensaklaran[6]. Nilai tegangan keluaran buck konverter dapat diatur dengan mengatur besar lebar pulsa (duty cycle) dari PWM (Pulse Width Modulation).

Buck konverter merupakan salah satu jenis switching konverter yang berfungsi menurunkan tegangan masukan sehingga tegangan keluaran akan bernilai lebih rendah[1]. Sebelumnya pernah dibuat tugas akhir oleh Fadri, R (2012) untuk menampilkan hasil output keluaran buck konverter masih menggunakan LCD (Liquid Cristal Display) dengan jenis LMB162A. Berdasarkan problematika yang telah penulis sampaikan di atas, maka penulis tergugah untuk melaksanakan penelitian yang berjudul: Rancang Bangun Buck Konverter dengan Antarmuka Visual Studio, dengan menggunakan visual basic untuk menampilkan output keluaran buck konverter dan pengaturan duty cycle dari buck konverter.

\section{Konverter DC - DC}

Konverter DC-DC digunakan untuk mengubah sumber tegangan DC menjadi sumber tegangan DC yang bersifat variabel. Menurut [9] ada empat jenis Konverter DCDC, yaitu:

a. Buck Konverter, menghasilkan tegangan keluaran lebih kecil dibandingkan tegangan masukan.

b. Boost Konverter, menghasilkan tegangan keluaran lebih besar dibandingkan tegangan masukan.

c. Buck-Boost Konverter, menghasilkan tegangan keluaran yang lebih kecil atau lebih besar dibandingkan tegangan masukan. Regulator ini juga disebut regulator pembalik.

d. Cuk Konverter, menghasilkan tegangan keluaran yang lebih kecil atau lebih besar dibandingkan tegangan masukan, tetapi polaritas tegangan keluaran berlawanan dengan polaritas tegangan masukan. 


\section{Buck Konverter}

Pada buck konverter, tegangan rata-rata output $\mathrm{V}_{\text {out }}$ lebih kecil dibandingkan tegangan input $\mathrm{V}_{\mathrm{s}}$. Rangkaian buck konverter dapat diperhatikan pada gambar 1 dibawah.

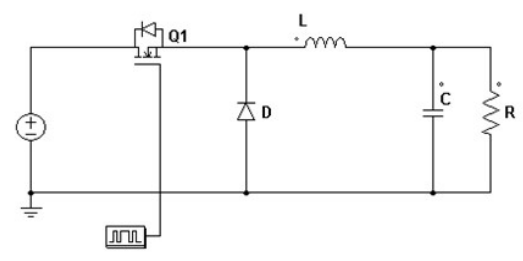

Gambar 1. Rangkaian Buck Konverter

Buck konverter dapat dioperasikan dalam 2 keadaan, yaitu keadaan saklar tertutup (state $O N$ ) dan keadaan saklar terbuka (state $O F F)$.

a. Keadaan Saklar Tertutup (State $O N$ )

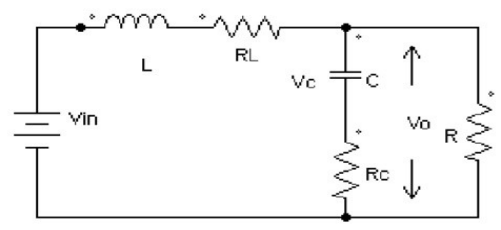

Gambar 2. Rangkaian Buck Konverter Pada Saat Saklar Tertutup

Gambar 2 posisi saat keadaan $O N$ yang merupakan rangkaian buck konverter saat saklar tertutup. Dimulai saat transistor $\mathrm{q}_{1}$ dihidupkan pada saat $\mathrm{t}=0$. Arus input yang bertambah mengalir melalui filter induktor $\mathrm{L}$, filter kapasitor $\mathrm{C}$, dan beban resistor $\mathrm{R}$.

b. Keadaan Saklar Terbuka (State OFF)

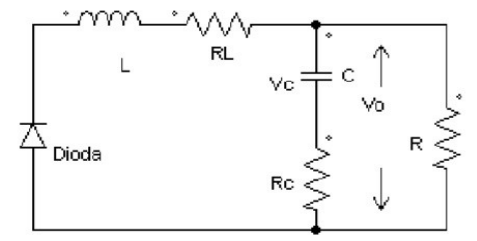

Gambar 3. Rangkaian Buck konverter Pada Saat Saklar Terbuka

Gambar 3 posisi saat keadaan (State $O F F$ ) yang merupakan rangkaian buck konverter saat saklar terbuka. Dimulai saat transistor $\mathrm{q}$ dimatikan pada $\mathrm{t}=\mathrm{t}_{1}$. Diode freewheeling $\mathrm{D}_{m}$ terhubung sebab energi yang terkandung pada induktor dan arus induktor tetap mengalir melalui L, C, beban dan diode D. Arus induktor mengalir menuju transistor $\mathrm{q}_{1}$ dihidupkan kembali pada siklus berikutnya.

\section{PWM (Pulse Width Modulation)}

PWM (Modulasi Lebar Pulsa) adalah suatu cara merubah lebar sinyal atau tegangan yang dinyatakan dengan gelombang pulsa dalam suatu perioda[11]. PWM merupakan sinyal digital berupa gelobang petak dimana duty cycle dari gelombang dapat diatur untuk menghasilkan keluaran sesuai dengan kebutuhan. Semakin besar lebar pulsa 
maka akan semakin besar pula keluarannya[12]. Sinyal PWM beroperasi pada frekuensi $500 \mathrm{~Hz}$. Setiap siklus nilainya mulai dari 0 sampai 255. Bentuk dari siyal PWM ditunjukan pada Gambar 4.

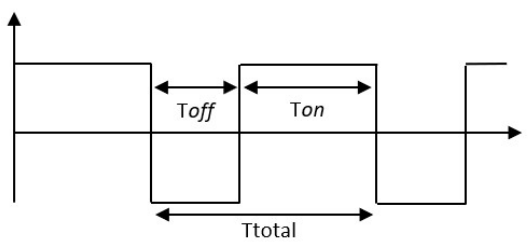

Gambar 4. Sinyal PWM

Waktu ketika tegangan output ada pada posisi high disebut Ton, sedangkan waktu ketika tegangan output ada pada posisi low disebut Toff. Jumlah waktu satu siklus ketika Ton dan Toff disebut Ttotal.

\section{Arduino Uno}

Arduinoi merupakani boardi mikrokontroler yangi berjenis iopen isource, yang artinya kita bisa langsung mamakainya maupun memodifikasinya. Untuk membuat, melakukan kompilasi dan meng-upload program ke arduino maka digunakan software Arduino IDE.

Arduino yang digunakan pada tuagas akhir ini adalah jenis Arduino Uno. Pada Arduino Uno terdapat mikrokontroler Atmega 328 (kepingan yang berfungsi untuk bertindak sebagai komputer). Operasi berbasis waktu dapat dilaksanakan dengan tepat dikarenakan terkandungnya mikroprosesor serta kelengkapan dengan oscillator $16 \mathrm{MHz}$ serta regulator atau supply sebesar 5 volt.

\section{Metal Oxide Semiconductor Field Effect Transistor (MOSFET)}

Komponen dengan kecepatan switching yang sangat kencang bahkan kecepatan switching memiliki orde nanodetik dan dikendalikan oleh tegangan serta memerlukan arus masukan yang kecil merupakan beberapa ciri-ciri dari MOSFET[2]. Apabila kecepatan tinggi diperlukan maka MOSFET merupakan komponen terbaik karena MOSFET dapat bekerja pada frekuensi 20KHz-200KHz.

Prinsip dasarnya perumpaan dari cara kerja MOSFET dapat dilihat seperti pada pengaturan aliran air pipa menggunakan kran. Elektron akan mengalir dari kaki Source (S) ke kaki Drain (D). Besarnya arus output akan sama dengan arus input $\left(\mathrm{I}_{\mathrm{D}}=\right.$ IS). Besar kecilnya tegangan yang masuk pada kaki Gate (G) akan mempengaruhi besar kecilnya arus. Namun dikarenkan tipisnya lapisan oksidasi pada MOSFET mengakibatkan MOSFET mudah rusak karena pembuangan elektrostatik (Electrostatic Discharge).

\section{METODA}

Metode penelitian ini berupa blok diagram, yaitu pernyataan gambar yang ringkas, dari gabungan sebab dan akibat antara masukan dan keluaran dari suatu sistem dapat dilihat pada Gambar 5. 


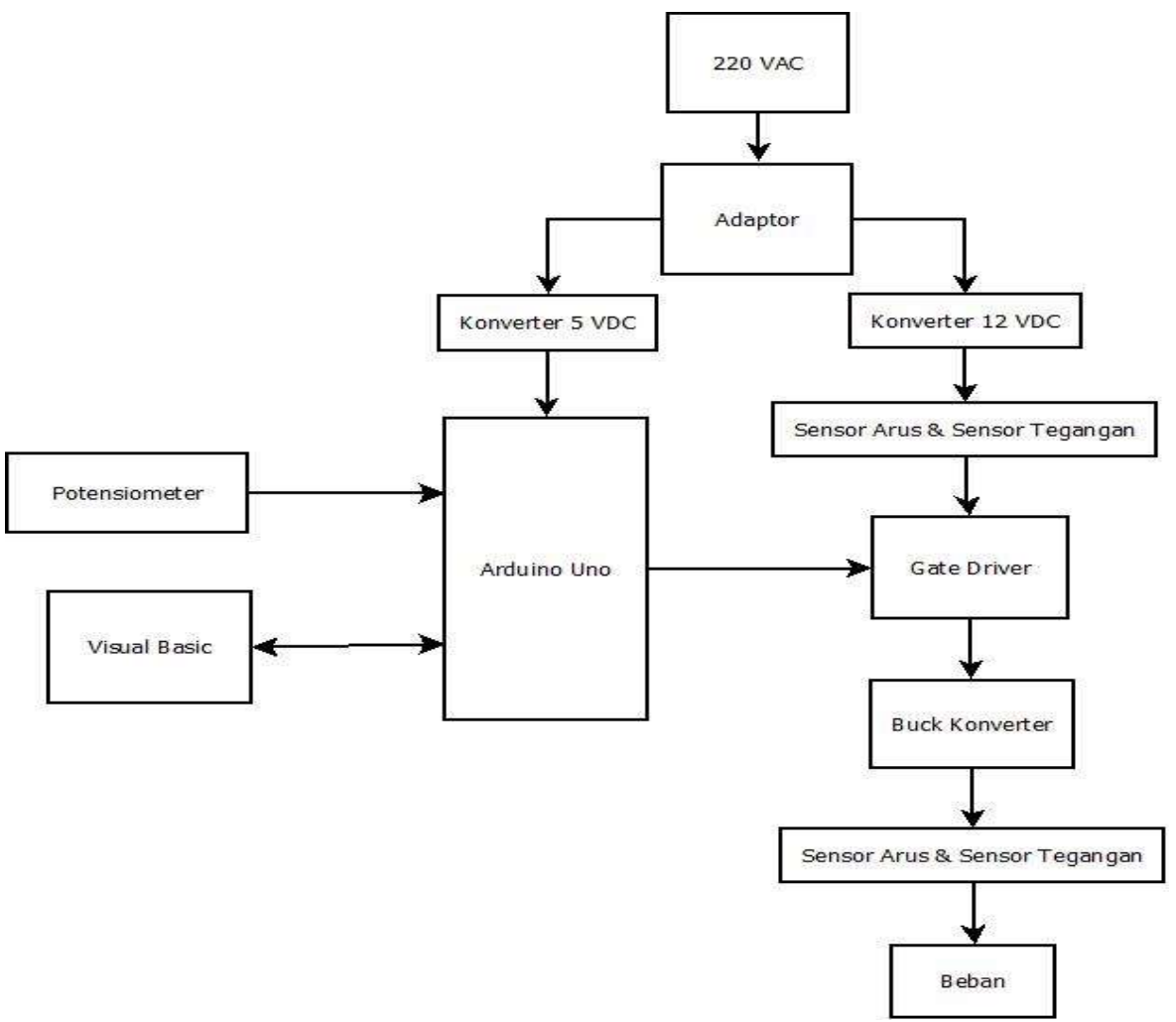

Gambar 5. Blok Diagram Perancangan rangkaian keseluruhan

Metode berikutnya yaitu Flowchart yang berfungsi sebagai acuan dalam membuat listing program serta berisi penentuan instruksi dari program yang akan dibuat. Flowchart pada sistem perancangan ini dapat diperhatikan pada gambar 6 .

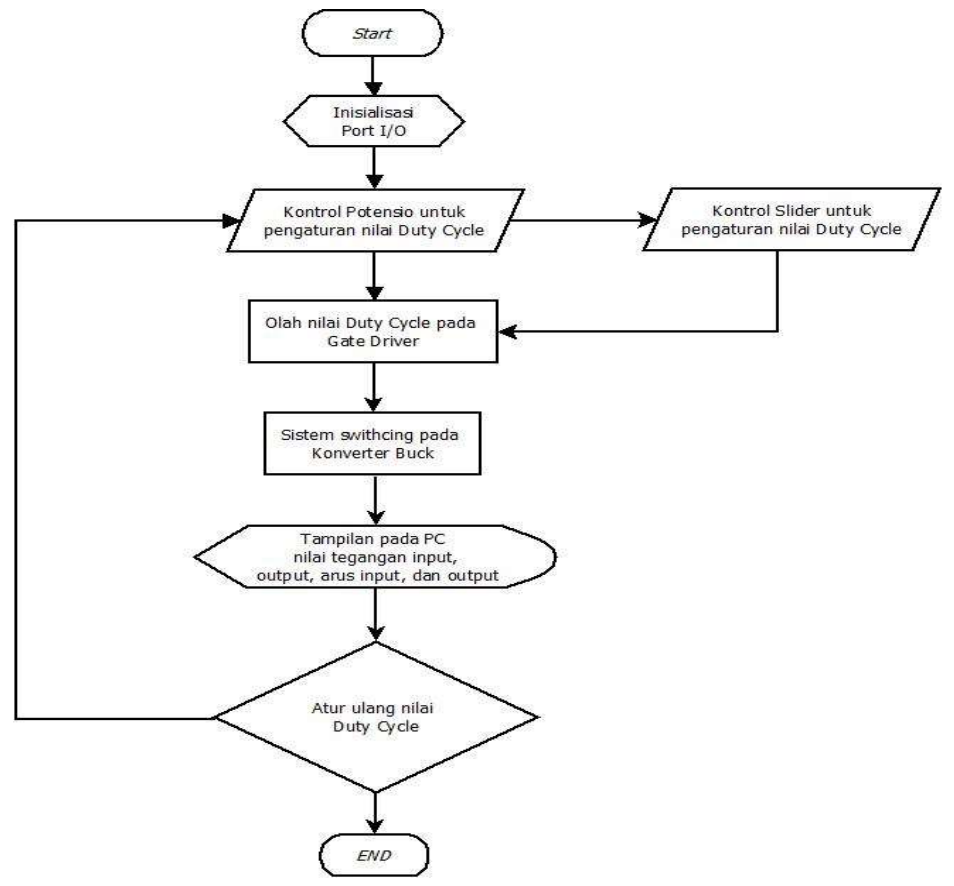

Gambar 6. Flowchart kerja alat 


\section{HASIL DAN PEMBAHASAN}

Dalam pengujian buck konverter ini dilakukan dengan memberikan tegangan 24VDC ke input rangkaian buck konverter dan mengatur nilai duty cycle dari $10 \%$ hingga 90\%. Beban yang digunakan adalah lampu bolham motor dengan nilai tahanan $4,11 \Omega$. Titik ukur pengujian ini terletak pada keluaran rangkaian buck konverter. Gambar 7 adalah alat buck converter yang dimaksudkan.

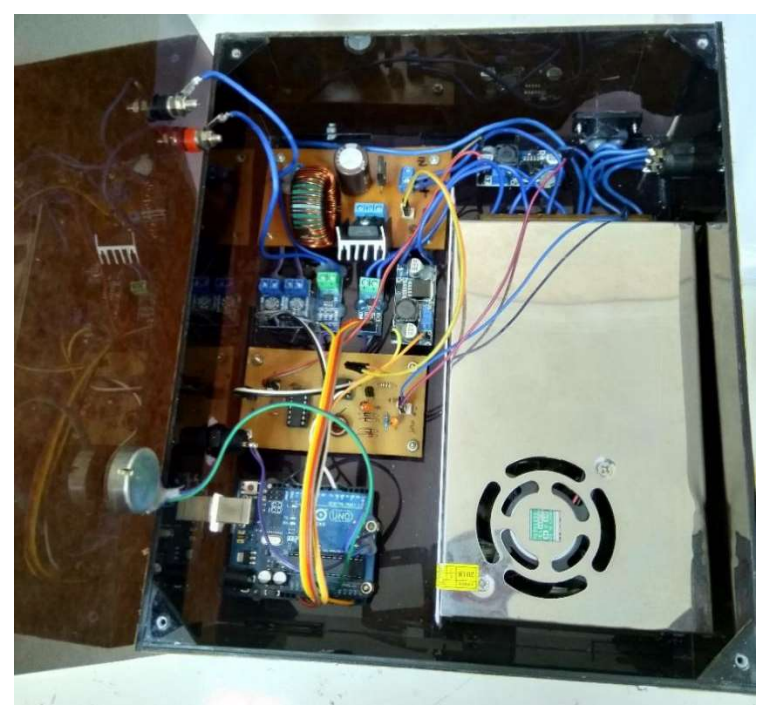

Gambar 7. Penampakan alat buck konverter

Gambar 8 merupakan tampilan keseluruhan dari software Visual Studio 2012 pada pengujian keluaran buck konverter yang ditunjukan pada gambar 8 .

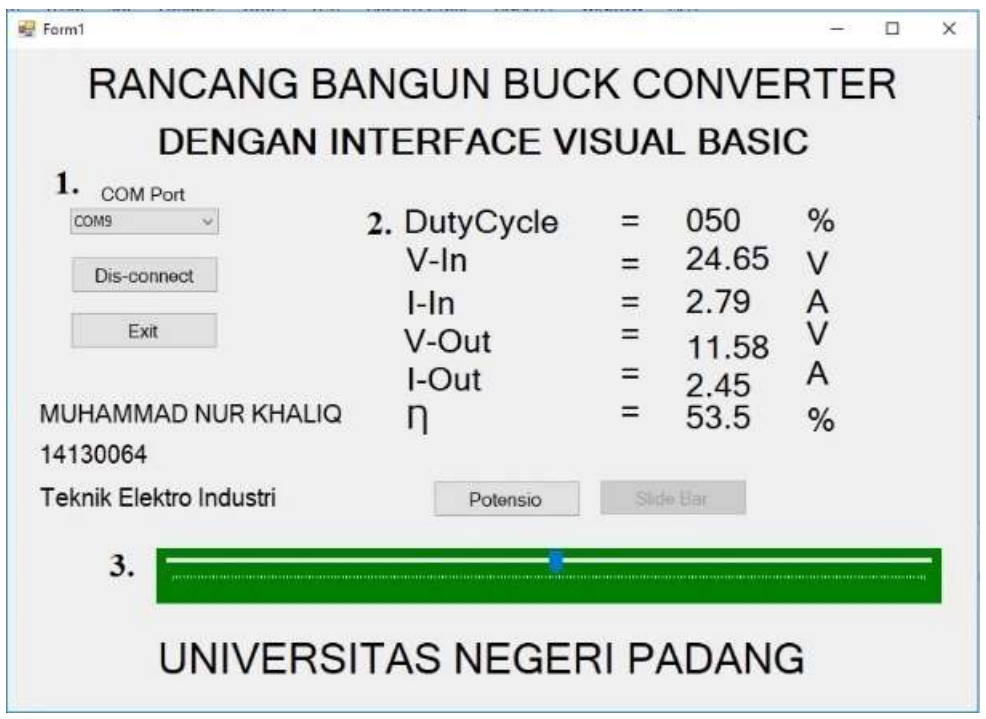

Gambar 8. Tampilan Visual Studio Secara Keseluruhan

Pada gambar 8 terdapat tiga bagian yang ditunjukan dengan angka. Bagian 1 merupakan bagian komunikasi serial. Terdapat dua button, yang pertama yaitu Connect/Dis-connect sebagai perintah untuk mengkoneksikan Visual Basic dengan 
Arduino Uno, yang kedua yaitu Exit sebagai perintah untuk keluar dari aplikasi, dan sebuah combo box yang berfungsi untuk pemilihan Port komputer. Selanjutnya pada bagian 2 merupakan bagian penampilan duty cycle, pembacaan sensor tegangan, sensor arus, dan efisiensi dari rangkaian buck konverter. Bagian 3 merupakan pengatur duty cycle dengan track bar dari rangkaian buck konverter. Terdapat opsi untuk memilih pengaturan duty cycle dengan potensiometer atau track bar.

Berikut beberapa pengujian yang telah dilakukan untuk memperoleh data-data dari setiap bagian alat.

\section{Pengujian Arduino Uno}

Pengujian rangkaian mikrokontroler Arduino Uno bertujuan untuk mengetahui apakah rangkaian sudah bekerja dengan baik. Rangkaian mikrokontroler Arduino Uno pada tugas akhir ini umumnya difungsikan untuk menghasilkan sinyal PWM yang nantinya akan digunakan sebagai pengatur pensaklaran untuk gate MOSFET pada rangkaian buck konverter. Berikut bentuk gelombang sinyal PWM yang dihasilkan oleh mikrokontroler Arduino Uno

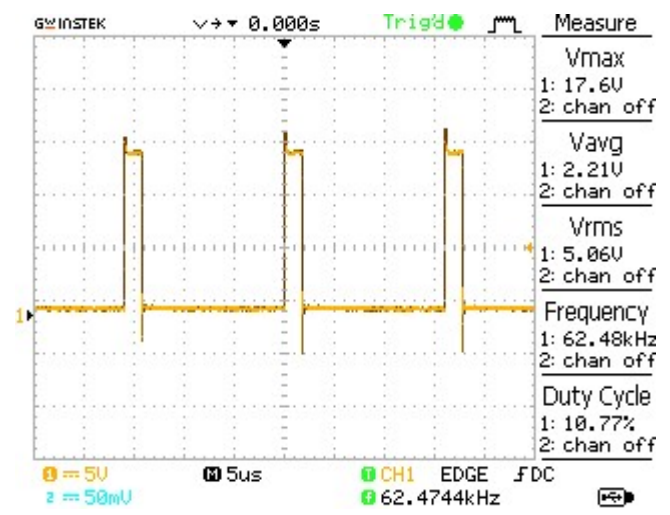

Gambar 9. Bentuk gelombang keluaran PWM dari mikrokontroler Arduino Uno saat duty cycle bernilai $10 \%$

Gambar 9 adalah salah satu bentuk gelombang keluaran PWM dari mikrokontroler Arduino Uno. Pengukuran dilakukan dengan cara menghubungkan probe oscilloscope ke port 2 mikrokontroler Arduino Uno, dan ground clip oscilloscope dihubungkan ke GND mikrokontroler Arduino Uno. Besarnya nilai duty cycle yang diberikan pada gambar 9 adalah sebesar $10 \%$.

\section{Pengujian Gate Driver}

Pengujian rangkaian gate driver ini dilakukan dengan cara menghubungkan rangkaian gate driver dengan keluaran adaptor 5 VDC, dan menghubungkan keluaran sinyal PWM yang dihasilkan oleh mikrokontroler Arduino Uno ke bagian input sinyal rangkaian gate driver dan melihat gelombang keluaran yang dihasilkan gate driver menggunakan oscilloscope. Titik ukur pengujian ini terletak pada keluaran rangkaian gate driver. 


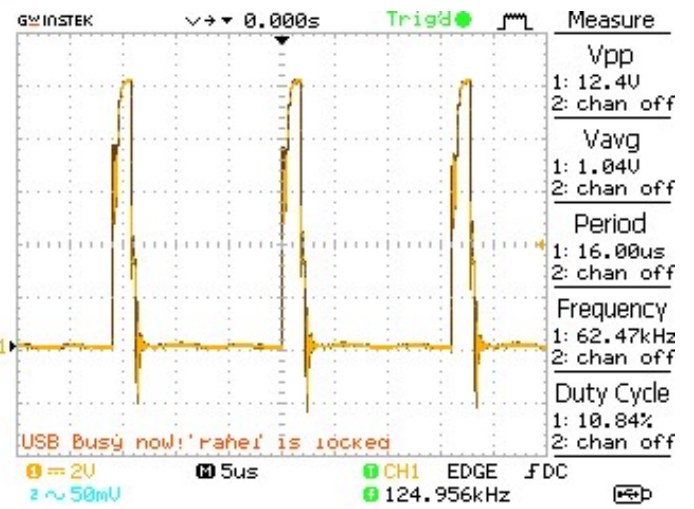

Gambar 10. Gelombang output gate driver duty cycle sebesar 10\%

Gambar 10 memperlihatkan bentuk gelombang keluaran dari gate driver. Pengujian yang dilakukan dengan cara memberikan nilai duty cycle sebesar $10 \%$ ke input sinyal gate driver, menghubungkan probe oscilloscope ke pin positif keluaran gate driver, dan ground clip oscilloscope dihubungkan ke pin negatif keluaran gate driver.

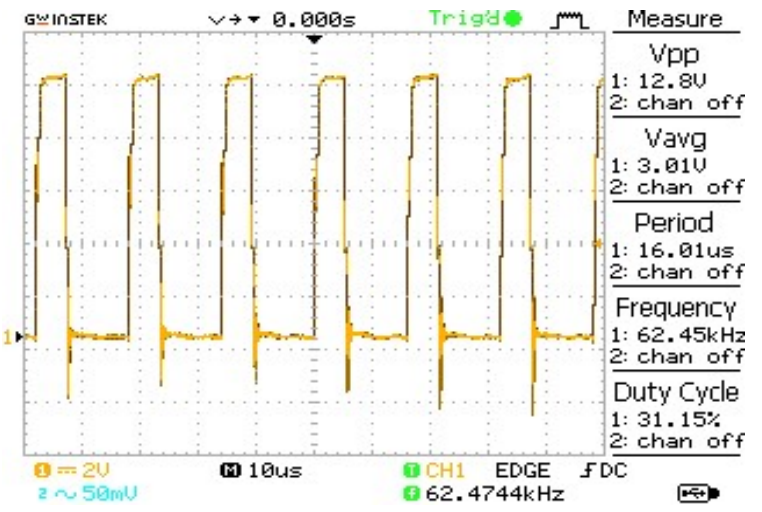

Gambar 11. Gelombang output gate driver duty cycle sebesar $30 \%$

Gambar 11 memperlihatkan bentuk gelombang keluaran dari gate driver. Pengujian yang dilakukan dengan cara memberikan nilai duty cycle sebesar $30 \%$ ke input sinyal gate driver, menghubungkan probe oscilloscope ke pin positif keluaran gate driver, dan ground clip oscilloscope dihubungkan ke pin negatif keluaran gate driver.

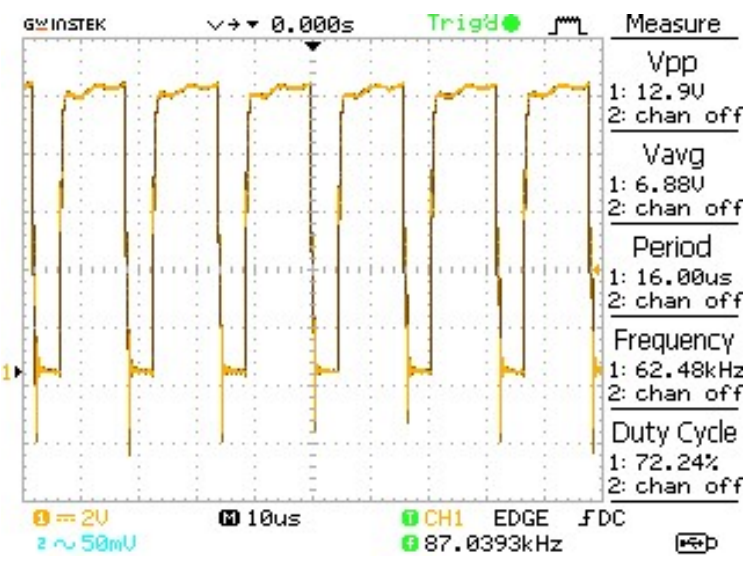

Gambar 12. Gelombang output gate driver duty cycle sebesar $70 \%$ 
Gambar 12 memperlihatkan bentuk gelombang keluaran dari gate driver. Pengujian yang dilakukan dengan cara memberikan nilai duty cycle sebesar $70 \%$ ke input sinyal gate driver, menghubungkan probe oscilloscope ke pin positif keluaran gate driver, dan ground clip oscilloscope dihubungkan ke pin negatif keluaran gate driver.

\section{Pengujian Buck Konverter}

Dalam pengujian buck konverter ini dilakukan dengan memberikan tegangan 24VDC ke input rangkaian buck konverter dan mengatur nilai duty cycle sebesar $10 \%$, $20 \%, 30 \%, 40 \%, 50 \%, 60 \%, 70 \%, 80 \%$, dan $90 \%$. Beban yang diberikan adalah 2 buah bolham lampu motor yang dipasangkan secara seri sehingga menghasilkan tahanan

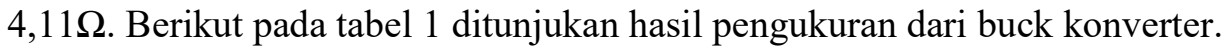

Tabel 1. Pengukuran Buck Konverter dengan beban R 4,11

\begin{tabular}{ccccccc}
\hline NO & $\begin{array}{c}\text { Duty Cycle } \\
\mathrm{D} \\
(\%)\end{array}$ & $\begin{array}{c}\text { Arus } \\
\text { Input } \\
\text { Iin } \\
(\text { Ampere) }\end{array}$ & $\begin{array}{c}\text { Tegangan Input } \\
\text { Vin } \\
\text { (Volt) }\end{array}$ & $\begin{array}{c}\text { Arus Output } \\
\text { Iout } \\
\text { (Ampere) }\end{array}$ & $\begin{array}{c}\text { Tegangan } \\
\text { Output } \\
\text { Vout } \\
(\text { Volt })\end{array}$ & $\begin{array}{c}\text { Efisiensi } \\
(\%)\end{array}$ \\
\hline 1 & 10 & 1,17 & 24,53 & 0,63 & 2,05 & 17,74 \\
2 & 20 & 1,68 & 24,56 & 0,65 & 4,27 & 38,34 \\
3 & 30 & 2,26 & 24,58 & 0,63 & 7,28 & 60,09 \\
4 & 40 & 2,63 & 24,53 & 1,23 & 9,67 & 79,58 \\
5 & 50 & 2,79 & 24,60 & 2,37 & 1,87 & 56,06 \\
6 & 60 & 2,89 & 24,58 & 2,95 & 14,12 & 55,97 \\
7 & 70 & 2,65 & 24,43 & 2,42 & 16,44 & 71,41 \\
8 & 80 & 3,55 & 24,51 & 2,74 & 18,67 & 94,46 \\
9 & 90 & 3,63 & 24,53 & 3,43 & 21,04 & 98,74 \\
\hline
\end{tabular}

Dari pengkuran diatas dapat dilihat penurunan tegangan output sebanding dengan penurunan duty cycle. Penurunan tegangan output dapat dilihat pada gambar 13 .

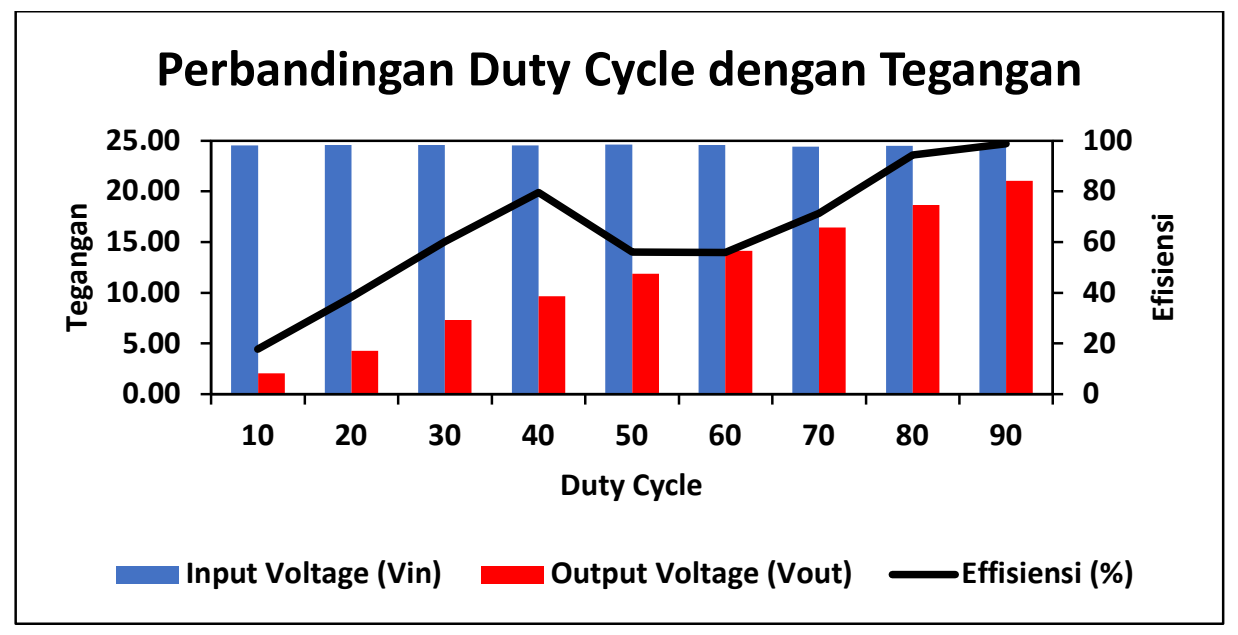

Gambar 13. Grafik Tegangan Output

\section{SIMPULAN DAN SARAN}

Berdasarkan hasil pengujian, pengukuran, dan analisa rangkaian serta program pada perancangan PWM digital untuk buck konverter yang telah dikerjakan, kontrol keluaran buck konverter dapat diatur dengan menggunakan dua buah kontrol, yakni kontrol 
dengan potensiometer dan kontrol menggunakan track bar pada interface visual basic. Perubahan nilai tegangan keluaran buck konverter berkisar antara 24 VDC sampai dengan tegangan yang lebih rendah yang dapat diubah dengan cara mengatur nilai duty cycle yang berkisar antara 10\% sampai 90\%. Pada saat pengujian, hasil tegangan yang ditampilkan dan tegangan perhitungan normal dengan beban bolham lampu motor yang dipasang seri sehingga menghasilkan nilai $4,11 \Omega$.

\section{REFERENSI}

[1] Ahadi, Khalif (2012) Rancang Bangun Buck Converter 12 Volt 60 Ampere Menggunakan P-Channel Mosfet dan IGBT Tipe N. Jurnal Ketenagalistrikan Dan Energi Terbarukan Vol. 11 No.1 Juni: 53 - 66.

[2] Alma'a, R. P., \& Handaga, I. B. (2017) Power Amplifier Kelas D Self Oscillating Dengan Power Mosfet Irfp4227, Irfp250n Dan Irfp460 (Doctoral dissertation, Universitas Muhammadiyah Surakarta).

[3] Badri, Sesrima. (2019) Rancang Bangun Konverter Boost Yang Terintegrasi Dengan Graphic User Interface. Jurnal MOTIVECTION ISSN: 2655-7215

[4] Fadri, Rahmanda., dkk. (2018) Studi Komparaatif Pengendali PI dan PID pada Tegangan Keluaran Buck Konverter Berbasis Mikrokontroler Arduino Uno. Jurnal INVOTEK ISSN: 1411 - 3411 Vol. 17, Februari No. 2.

[5] Fitriadi dan M. Imran Hamid. (2016) Desain Rangkaian Gate-Driver Untuk Konverter yang Bekerja dengan Voltage Mode Control. Jurnal JNTE ISSN: $2302-$ 2949 Vol: 5, Juli No. 2.

[6] Hart, Daniel W. (1997) Introduction to Power Electronic. Prentice Hall.

[7] Husnaini, Irma dan Krismadinata. (2017) Komparasi Pengendalian PI dan PID untuk Tegangan Keluaran Konverter Buck. Jurnal JNTE ISSN: 2302 - 2949 Vol. 6, November No. 3.

[8] Rashid, Muhammad. (1999) Elektronika Daya. Jakarta: Prenhallindos.

[9] Rashid, Muhammad. (1993) Elektronika Daya, Rangkaian, Devais,dan Aplikasinya. Terjemahan oleh Ary Prihatmanto. (1999) Jakarta: Prenhallindo.

[10] Rashid, Muhammad H. (2011) Power Electronics Handbook $3^{\text {rd }}$ Edition. UK: Elsevier Inc.

[11] Rosas-Caro, J. C., Ramirez, J. M., Peng, F. Z., \& Valderrabano, A. (2010) A DCDC multilevel boost converter. IET Power Electronics, 3(1), 129-137.

[12] Yusiana, V. (2018) Perancangan Boost Konverter Sebagai Penguat Umpan Balik Charger Control Baterai Pada Panel Surya. Jurnal Civronlit Unbari, 3(2), 98-103. 